\title{
Pedagogy and Heutagogy Approach in Idris Sardi's Musical Development
}

\author{
Fu'adi Fu'adi ${ }^{1}, *$, Putu Sudira ${ }^{2}$, Kun Setyaning Astuti ${ }^{1}$ \\ 1 Department of Music Education, Faculty of Languages and Arts, Universitas Negeri Yogyakarta, Indonesia \\ 2 Department of Technology and Vocational Education, Graduate School of Universitas Negeri Yogyakarta, Indonesia \\ * Corresponding author. Email: fuadi@uny.ac.id
}

\begin{abstract}
Idris Sardi is an Indonesian music figure who is widely recognized by the public for his achievements and musical works. This study discusses the musical development of Idris Sardi in pedagogy and heutagogy approaches. A qualitative method was used with a narrative approach. Data collection was conducted through observation techniques, in-depth interviews and documentation. Data was analyzed by organizing data and creating codes, describing codes in chronological themes, developing interpretations, and visualizing data. The results of the study are: First, Idris Sardi's Pedagogy approach includes informal learning with his father (M. Sardi) and formal learning with the guidance of Nicolai Valvolomeyef at the Indonesian Music School, Yogyakarta. Second, Idris Sardi's heutagogy approach begins with the emergence of Idris Sardi's distinctive style of music playing, music formation, and music repertoire by exploring ethnic musics in Indonesia.
\end{abstract}

Keywords: Pedagogy, Heutagogy, Idris Sardi, Musical development.

\section{INTRODUCTION}

The development of a musician's capability can be traced from the initial process of learning music to the advanced level, which embodies his natural and original work. Through the learning process, many benefits can be taken to develop the world of education, in this case, music education. There are quite a number of musicians who work on the violin instrument, marked by the increasing number of schools, both formal and nonformal, that hold violin lessons. The growth of various orchestra groups in several cities also shows that violinists have grown.

The increasing number of violinists has not been matched by adequate musical capabilities. There are many problems in music education. Machfauzia [1] revealed that music education students did not have a good interpretation, because audio media had not been used in learning. Interpretation skills and good musical instrument playing techniques can be learned from successful musicians, one of which is Idris Sardi. This article describes the early stages of development until the Idris Sardi's violin playing characteristics appear.

Idris Sardi has actively held music concerts in America, Europe, Asia, and Russia [2]. In 1955, Idris Sardi became a concertmaster at the Djakarta Studio Orchestra (OSD) under Syaiful Bachri [3]. Apart from being a violinist, Idris Sardi also has other skills, namely composing songs, making arrangements for recordings since 1963, and has made more than two hundred musical illustrations for films. Idris Sardi has won various awards, including the best film music director with ten Citra Awards at the Indonesian Film Festival (FFI), several trophies at the Asian Film Festival, and other award certificates [4].

Pedagogy and heutagogy approaches are applied in the violin learning approach by Idris Sardi. Pedagogy 
comes from the root words paidos (child: child) and ago (lead: lead). The lexical meaning of pedagogy is to lead the children (to lead the child). The pedagogy paradigm is that students' self-concept in learning considered immature and still dependent on others. Students still need guidance, direction, assistance, mentoring, and supervision from teachers. In external motivation, there are assessments, punishments, awards, and competitions [5].

Pedagogy is an action that implies a relationship between individuals, based on concern for one another. Transferring this relational understanding of pedagogy to the realm of education, the teacher stands in a pedagogical relationship with students. Teachers are placed in a position to direct students towards academic and personal growth, the nature of teaching and pedagogical action is driven by constant affirmation and constant determination [6].

Heutagogy is also referred to as self-determined learning [7]. Heutagogy can be seen as a development of pedagogy and andragogy, where students have the autonomy to determine and direct their learning paths and processes [8]. Learning contracts are made, followed by learning activities that foster critical thinking and creativity, and finally learning outcomes are assessed [9]. In two-round learning, students consider the problem and the actions and outcomes that result and reflect on the problem-solving process and how it affects the learner's own beliefs and actions [10].

\section{METHOD}

\subsection{Research Design}

This research uses a qualitative method with a narrative approach. As a form of qualitative research, the narrative usually focuses on studying one person, collecting data through storytelling, reporting on individual experiences, and discussing the meaning of those experiences [11].

\subsection{Informants}

The informants of this research were selected based on their ability to provide detailed information and genuinely understand the figure of Idris Sardi. The informants come from the closest family, students, and colleagues of Idris Sardi. Creswel [12] states that in narrative research, many examples are found with one or two individuals unless a larger group of participants is used to develop the story collectively. The subject of this research is Idris Sardi, and this research reveals Idris Sardi's music learning process from pedagogy and heutagogy approaches.

\subsection{Data Collection Technique}

The research stage begins with a preliminary study of Idris Sardi, followed by data collection through observation techniques, interviews with informants, and documentation from print, audio, video media about Idris Sardi. The author also communicates intensively via telephone, WhatsApp, WA video and email.

\subsection{Data Analysis}

Data analysis was carried out by processing and preparing data for analysis through making transcripts of all interviews, scanning materials, making field notes, and sorting different data depending on the source of information [13]. The author then reads all the data [14]. The next step is data reduction by selecting, focusing, simplifying, abstracting, and transforming the data that appears in field notes or data transcripts [15]. The next step is to make coding and categories [16], then interpret the data by identifying the material context and representing and visualizing the data by rearranging the story and providing deep meaning from the story [17]. The validity of the data through triangulation of techniques, sources, member checks with participants, and clarifying the researcher's bias.

\section{RESULT AND DISCUSSION}

Idris Sardi's violin learning is a long journey full of twists and turns. It takes determination, enthusiasm, creativity, extrinsic motivation, and others to go through all stages of learning to produce adequate abilities. Adequate violin playing capabilities will expedite the musician in carrying out his musical duties or work.

\subsection{Pedagogy}

Idris Sardi's musical education began informally when Idris Sardi was five years old. It was very difficult to get a violin with a small size. M. Sardi then gave an example of how to swipe the violin as a basic technique. Every eight o'clock in the morning, Idris Sardi was invited to see a musical performance on Radio Republik Indonesia (RRI). In the afternoon, M. Sardi taught the violin and piano. In the evening, Idris Sardi was invited to Lokasari (a gathering place for Dutch and Chinese people) to see musicians playing Latin songs and Jazz [18]. Idris Sardi's musical talent began to develop by identifying various musical instruments, various songs, and chord progressions. At nine, Idris Sardi began to learn to play the violin at adult size. This makes it difficult to play it. His little fingers must be able to reach certain notes on the violin. Because of his strong desire, Idris Sardi tried hard to play it.

Idris Sardi received formal music education when Nicolai Valvolomeyef, a Russian cellist who is a member of OSD, asked him to study music at the Indonesian Music School (SMIND) in Yogyakarta. SMIND is the first formal music school established by 
the Government of Indonesia. Idris Sardi was trusted by Radio Republik Indonesia in Yogyakarta to play classic songs such as Humoresque every Sunday at 10.00.

The period of studying classical music in Yogyakarta had to be stopped because in 1953 because of Idris Sardi's father died, then he returned to Jakarta [19]. As the eldest son of the family, Idris succeeded his father. As the breadwinner for the family, Idris Sardi works to make ends meet. Idris Sardi's music education can be categorized as vocational education, which is an educational process that directs students to work and fulfill all kinds of needs in their lives. Idris Sardi's musical competence from learning music in Jakarta and Yogyakarta can be used to work as an orchestra musician.

Idris Sardi has the view that in starting violin learning, students must have awareness that their talent is a gift from God. This can be interpreted that no matter how much talent is given, it must be grateful for by trying as much as possible to develop it continuously. The ability to play the violin can be mastered well through study and hard practice. The renowned Japanese violin teacher [20] is of the view that musical talent does not just happen. This shows the need for consistent efforts to develop talent. This balance between talent and hard work is also in accordance with the principle of learning the violin by Galamian [21] that mastering the violin is a long and difficult process. The application of practice and perseverance is needed to achieve the goal. As for talent, it helps to make it easier, but you can't succeed without hard work in practice. Idris Sardi combines talent and hard work to achieve his original play. Since childhood, Idris Sardi was educated with full discipline. Five o'clock in the morning already practicing the violin, practicing intonation accurately. Even though Idris Sardi has extraordinary musical talent, he still trains hard.

In addition to hard work, discipline is the main key in practicing the violin. Discipline in using practice time will positively impact mastery of violin playing techniques. Idris Sardi views discipline in practice as part of obtaining optimal results. Jorgensen argues that there is an explicit relationship between the duration of musical practice and the level of achievement of musical playing skills [22].

Idris Sardi prioritizes complete mastery of technique in every music learning process. Through good technical mastery, the aesthetic values of a violin show can be expressed. This principle of Idris Sardi does not conflict with the Galamian violin learning method. Basically, students must be good intermediaries so that their musical ideas can be realized in their entirety [23]. This is in line with Gerle's statement that learning strategies such as exercises with a slow tempo, sequential, and repeated are more useful [24].

\subsection{Heutagogy}

\subsubsection{Learn Different Kinds of Music}

The findings in the interview clearly state that Idris Sardi has three important things in studying classicalWestern music genres, including practicing slowly, practicing songs for each small part, and managing time in practice. Idris Sardi trains songs with a fast tempo by reducing the tempo as slowly as possible. The slow tempo allows students to know and feel how the righthand swipes and the left-hand aims the notation on the fingerboard. The management of this slow tempo exercise is in accordance with Kinsey's [25] opinion that often times when students have gone through the exercise slowly to see what and why to do, students can understand the nature of the difficulties that must be overcome so that the learning has value for students. Sonatas and violin concertos have several movements that are pretty long. This causes sonatas and concertos cannot be studied in full and in detail at one time. Idris Sardi trains the song per part in detail and repeatedly. Gerle explains that the repetition of small parts of difficult-to-play notation should continue until a level of comfort and fluency is achieved. Kinsey explains that students will automatically learn that persistence is the key through constant application and careful attention to certain details [26].

Idris Sardi manages the practicing time for the violin, referring to the current students who have various activities given by the teacher at school. This affects the time available to practice the violin. The limited-time is used to the fullest to practice the songs on a piece-by-section basis, so technical difficulties will be easily resolved. You can take an example of a twobar practice every day, then the details of technical problems will be solved, and the practice will feel light and fun. The short duration of practice developed by Idris Sardi is directly proportional to the practice of the violin carried out by Auer [27], who suggests practicing the violin for no more than 30-40 minutes, then taking a 10-15 minute break and then practicing again. Exercise that is too long will actually cause physical and mental fatigue. Galamian [28] divides the time in practicing the violin, namely Buiding time (basic practice and technical problems), Interpreting time (musical expression), and Performing time (music playing with repeated difficulty analysis). Idris Sardi's principles through slow practice and each part will encourage more optimal violin learning outcomes.

Idris Sardi in studying popular music includes following the development of popular music, selecting songs, and giving the popular music color with the characteristics of his playing. Idris Sardi is very open to various genres of music, including popular music. Popular music that is growing rapidly is followed by choosing suitable songs for playing with the violin. Idris Sardi is not half-hearted in music production, so the popular songs he will play are arranged in musical arrangements full of musical characters. 
In studying keroncong music and ethnic music, Idris Sardi studied by looking for teachers of keroncong violin and ethnic music, such as Malay music, cokek, lenong and others. Idris Sardi learned directly from these teachers and even lived with them. Idris Sardi's togetherness in their lives is intended to explore feelings, and understand the artists difficulties, so that an inner experience can be obtained that can support him in interpreting keroncong songs, Malay music, cokek and others. This learning is the method chosen by Idris Sardi so that the technique of playing the keroncong and ethnic violin can be mastered well, as well as the taste of the music can be expressed appropriately. Idris Sardi's activities in seeking knowledge by meeting ethnic musicians can be a reference for violin students in complementing the abilities obtained from the school. Musical culture reflects the traditions and customs of the society in which an individual grows and lives, forms a musical identity, shapes that individual's musical characteristics and can direct appropriate musical learning situations [29]. Thus, violin students will continue to grow and develop by absorbing various potentials in the surrounding environment. This is directly proportional to Regelski's opinion that music education should help students find their values and ways of acting to achieve independence and freedom as individuals [30].

\subsubsection{Music Performing}

Musicians in performing music require preparation both technically and mentally. Almost every musician feels nervous before a musical performance and making performance difficult by inhibiting the violinist's physical and emotional abilities. Auer [31] assumed that no hypnotic or medical drug could treat nervous effects. Findings related to this problem, Idris Sardi has a way to overcome it, always remember God, both when he is about to start rehearsals and performances. Focusing on playing music for God naturally gets rid of things that can distract you from playing the violin. A strong belief that good playing comes from God will encourage musicians to play their best.

A good interpretation of Idris Sardi's music can produce a violin playing with feelings that focus on God, mind, and heart. The ability to play the violin like this is not easy, it requires understanding, skill, and the right method. Idris Sardi has always realized that God has given humans a perfect physique and the ability to express feelings through music, so that he believes that God will provide help. Aspects of the mind become an important thing covering everything about the material brought in the show. The processing of material regarding the song's theme of the, dynamics, and other technical issues has been well prepared in the rehearsal before the performance. The involvement of the heart in playing the violin is important as an effort to convey the message contained in the song to the audience. Idris Sardi's principle in processing this interpretation is in line with the opinion of Galamian [32] that for a successful performance, it is not enough to have technical ability alone, the performer must have a creative imagination and a personal emotional approach to the song. Galamian also explained that the main problems in the performance came from several factors, namely physical factors, mental factors and aestheticemotional factors. Physical factors relate to the anatomy of each individual's body including the size of fingers, hands, arms, and muscle flexibility as well as psychological functions related to playing movements and the muscle movements that cause them. Mental factors, which are the ability of the mind to prepare, direct and supervise muscle activity, and aestheticemotional factors, which are the capacity to understand and feel the meaning of music, plus an innate talent to project its expressive message to listeners [33].

Inadequate interpretation ability of violin students is closely related to the music learning process in vocational education. Violin teachers or music instructors can develop this in a way that is based on Idris Sardi's learning approach, namely by directing concentration to God, mind and heart. If these three things are done synchronously, it will produce music that can carry out its role as a medium of communication to the audience. In Idris Sardi's view, music is a language of taste that can bring out different musical experiences for listeners. Quality music will continue to be remembered, and conversely, music done with no variety will make the music monotonous.

\section{CONCLUSION}

The long and difficult process of learning the violin, if it is not managed properly, can make students less interested in the violin. This is understandable because there are various technical difficulties, and high enthusiasm in learning the violin. The presence of people around, such as parents, teachers, and friends greatly supports the development of students in learning the violin. This pedagogy and heutagogy approach can be used as a study material that a musician's success is not enough to rely on talent alone, but hard work, tenacity, and perseverance in practicing are the keys.

\section{ACKNOWLEDGMENTS}

The author would like to thank the participants for their willingness to take the time to interview and provide the necessary information, especially to Ms. NRS.

\section{REFERENCES}

[1] A. N. Machfauzia, S. A. Sayuti, and Djohan. Musical interpretation: case study in musical instrument practice learning vocational high 
school. Jurnal Pendidikan Vokasi, Vol. 8(2), 2018, pp. 193-203, DOI: $10.21831 /$ jpv.v8i2.19875

[2] Sunny, N. and H. S. Idris Sardi, Antara Biola dan Kehidupan. Vista, 1991.

[3] Sardono. Perjalanan Musik Di Indonesia. PT. Lithopica, 1983.

[4] F. Zon, Idris Sardi, Perjalanan Maestro Biola Indonesia. Fadly Zon Library, 2013.

[5] P. Sudira, Paradigma Baru Pembelajaran Vokasional Era Revolusi Industri 4.0, Membangun SDM Digital Among Kreativitas Dagang Inovasi. Yogyakarta: UNY Press. 2020.

[6] Cuenca. Alexander. Self-Study Research: Surfacing the Art of Pedagogy in Teacher Education. Journal of Inquiry \& Action in Education, Vol. 3(2), 2010.

[7] L. M. Blaschke, 'Heutagogy and lifelong learning: a review of heutagogical practice and selfdetermined learning', The International Review of Research in Open and Distance Learning, 2012.

[8] Narayan., Vickel., J. Herrington. Design principles for heutagogical learning: Implementing studentdetermined learning with mobile and social media tools. Australasian Journal of Educational Technology, Vol. 35(3), 2019.

[9] Maykut, Collen. Carol Wild, Nicole May. Heutagogy: Enacting Caring Science Practices. International Journal of Caring Sciences. JanuaryApril Vol. 12(1). 2019, p. 11.

[10] Chan, Choo Gui., Mohamed Amin Bin Embi \& H. Hashim. Primary School Teachers' Readiness Towards Heutagogy and Peeragogy. Asian Education Studies, Vol. 4, No. 1; ISSN 2424-8487 E-ISSN 2424-9033 Published by July Press, 2019.

[11] J.W. Creswell, Educational Research: planning, conducting, and evaluating quantitative and qualitative research, 4th ed. Copyright (C) 2012 by Pearson Education, Inc., 501 Boylston Street, Boston, MA 02116, 2012.

[12] J. W. Creswell, Cheryl, and N. Poth. Qualitative Inquiry \& Research Design Choosing Among Five Approaches, Fourth Edition. Thousand Oaks, California: SAGE Publications, Inc., 2018, p. 226.

[13] J. W. Creswell, N. Cheryl Poth, Qualitative Inquiry \& Research Design Choosing Among Five Approaches, Fourth Edition. Thousand Oaks, California: SAGE Publications, Inc., 2018, p. 264.

[14] J. W. Creswell, N. Cheryl, Poth. Qualitative Inquiry \& Research Design Choosing Among Five
Approaches, Fourth Edition. Thousand Oaks, California: SAGE Publications, Inc., 2018. p. 269.

[15] M. B. Miles, \& A. Huberman, Qualitative Data Analysis_ An expanded Sourcebook 2nd Edition. London: SAGE Publications, Inc. 1994, p. 10.

[16] B. Bogdan, \& S. K. Bilken, Quality research for education: An introduction to theory and methods (Fifth Edit). Pearson Education, Inc., 2007, p. 173.

[17] J. W. Creswell, N. Cheryl Poth. Qualitative Inquiry \& Research Design Choosing Among Five Approaches, Fourth Edition. Thousand Oaks, California: SAGE Publications, Inc, 2018.

[18] E. Mulyadi, Lebih Jauh Dengan Idris Sardi Kompas, 7 Juni 1987.

[19] 1976. Idris Sardi Yang Dari Lumpur Becek, Perjalanan Seniman Yang Selalu Risau. Sinar Harapan, 4 September.

[20] S. Suzuki, Nurtured by love: A new approach to education. New York: Exposition Press, 1969, p. 7.

[21] I. Galamian, Principles of violin playing and teaching. New Jersey: Prentice-hall, Inc., 1964, p. 93.

[22] H. Jorgensen, Instrumental performance expertise and amount of practice among students in a conservatoire. Music Education Research, 4(1), 2002, pp. 105-119. DOI: https://doi.org/10.1080/ 14613800220119804

[23] I. Galamian, Principles of violin playing and teaching. New Jersey: Prentice-hall, Inc., 1964, p. 5 .

[24] R. Gerle, The art of practicing the violin. London: Stainer \& Bell, 1983.

[25] H. Kinsey, The foundations of violin playing and musicianship. London: Longmans Green \& Co. 1954 , p. 36

[26] H. Kinsey, The foundations of violin playing and musicianship. London: Longmans Green \& Co. 1954 , p. 26

[27] L. Auer, Violin playing as I teach it. New York: Frederick A. Stokes Company., 1921, p. 47.

[28] I. Galamian, Principles of violin playing and teaching. New Jersey: Prentice-hall, Inc. 1964, p. 101.

[29] K. Çelenk, \& E. Lehimler, A study on learning styles of individuals receiving vocational music education. Journal of Education and Training Studies, Vol. 7(10), 2019, pp. 108. DOI: https://doi.org/10.11114/jets.v7i10.4414., p. 109. 
[30] T. Regelski, Teaching general music. New York: Schirmer Books, 1981

[31] L. Auer, Violin playing as I teach it. New York: Frederick A. Stokes Company., 1921, p. 193.

[32] I. Galamian, Principles of violin playing and teaching. New Jersey: Prentice-hall, Inc., 1964, p. 6.

[33] I. Galamian, Principles of violin playing and teaching. New Jersey: Prentice-hall, Inc., 1964, p. 3. 